\title{
Reduction of Microalgae by Copper Ion in Impressed Current Anti Fouling System for Biofouling Prevention in Saline Environment
}

\author{
Herman Pratikno ${ }^{1 *}$, Harmin Sulistiyaning Titah ${ }^{2}$, and Handayanu ${ }^{1}$ \\ 1 Department of Ocean Engineering, Faculty of Marine Technology, Institut Teknologi Sepuluh Nopember, \\ Keputih, Sukolilo, 60111 Surabaya, Indonesia \\ 2 Department of Environmental Engineering, Faculty of Civil, Environmental and Geo Engineering, Institut \\ Teknologi Sepuluh Nopember, Keputih, Sukolilo, 60111 Surabaya, Indonesia \\ * Corresponding author's e-mail: hermankelautan@gmail.com
}

\begin{abstract}
The biofouling causes corrosion in marine environment, also known as the biological corrosion. The biological corrosion occurs in the metal material on coastal buildings, offshore buildings, port buildings and shipboard. One method to prevent the biological corrosion is ICAF (Impressed Current Anti-Fouling). The study on the microalgae that cause biofouling was conducted in laboratory scale using a simple ICAF system. The variables were the operating time of the simple ICAF system, the strength of the electric current and the species of microalgae. The determination of cell number of microalgae was conducted using a Neubauer improved Hemocytomete method, while determination of the concentration of $\mathrm{Cu}$ ion was conducted using Atomic Absorption Spectrophotometry (AAS). The aim of the research was to determine of microalgae, Isochrysis galbana and Botryococcus sp, population reduction using ICAF system. On the basis of the results, the highest population reduction occurred in Isochrysis galbana and Botryococcus sp reaching $77.5 \%$ and 50\%, respectively. The highest concentration of $\mathrm{Cu}$ that was produced during the operation of the simple ICAF system reached $4.08 \pm \mathrm{mg} / \mathrm{L}$. In conclusion, ion $\mathrm{Cu}$ that was produced during the operation of the simple ICAF system can reduce the cell number of Isochrysis galbana and Botryococcus sp.
\end{abstract}

Keywords : biocorrosion, biofouling, impressed current anti-fouling, $\mathrm{Cu}$ ion, microalgae

\section{INTRODUCTION}

The marine building technology consists of coastal buildings, offshore buildings and port / pier buildings. One of the offshore marine structures is a production platform with complete equipment including faucets, tanks, cooling devices, heaters, generators, pumps. The sea water is the efficient mean used on board and coastal/ offshore buildings for the release of this heat (Allal et al., 2017).The cooling system can use the sea water; it is known as the sea water cooling system. However, the sea water cooling system has a deficiency. The quality of sea water that be used can affect the process in the cooling system.

Some of microorganisms such as bacteria, diatoms, microalgae were responsible for microfouling, meanwhile the adhesion of larger organisms such as algae, mussels and barnacles can cause macrofouling (Cao et al., 2011). The sea water pollution can cause increasing in the population of some microorganisms. The microorganisms that cause microbiofouling also grow well in a contaminated environment. On the basis of the study by Azam and Malfatti (2007), $1 \mu \mathrm{L}$ of surface seawater may consist of 10,000 viruses; 1,000 bacteria; 110 cyanobacteria; 10 eukaryotic algae and 10 protists that can affect the adhesion to produce the biofouling. Diatoms can attach directly to clean surfaces such as stainless steel and glass just after a few hours of immersion (Cooksey and Wigglesworth-Cooksey, 1995). The biofouling, known as biological corrosion, causes corrosion in the marine environment. Biological 
corrosion occurs in the metal material. One method to prevent the biological corrosion is ICAF (Impressed Current Anti-Fouling). The ICAF is a new corrosion preventing system that use a low electric current. The ICAF can cause the decay of some corrosive organisms. However, the effectiveness of this tool in inhibiting various types of bio-fouling has not been proven. The research used a simple power electric system and two materials as cathodes and cathode for determining the effectiveness of the system. The ion from anodes can be produced continuously to reduce the population of microorganisms. The designed ICAF system reactor uses direct current (DC), the cathode uses steel material commonly used in marine buildings, as well as a copper $(\mathrm{Cu})$ plate as an anode.

On the basis of the previous study, a reduction in the population of Pseudomonas fluorescens was $98.5 \%$. at $0.1 \mathrm{~A}$ electric current and $3 \mathrm{~min}$ of operating time (Pratikno and Titah, 2016). The reduction in the population of Pseudomonas fluorescens occurred due to the presence of the $\mathrm{Cu}$ ions that were released from the anode into the saline solution in the ICAF system. The $\mathrm{Cu}$ ions have the ability to kill microorganisms, including the Pseudomonas fluorescens. The Cu toxicity of the Pseudomonas fluorescens was indicated by the LC50 value of $16.8 \mathrm{mg} / \mathrm{L}$ (Botsford, 1998). Meanwhile, the percentage reduction in the population of Vibrio algynoliticus and Escherichia coli reached $99.4 \%$ and $90 \%$ (Pratikno et al., 2019a; Pratikno and Titah, 2017). The concentration of the $\mathrm{Cu}$ ion during the operation of the ICAF system reached $17.85 \pm 0.01 \mathrm{mg} / \mathrm{L}$ to 20.9 $\pm 0.03 \mathrm{mg} / \mathrm{L}$. It indicated that a simple ICAF system can reduce the population of Pseudomonas fluorescens, Vibrio algynoliticus and Escherichia coli with different variations of operating time and electric currents. According to Pratikno et al. (2019b), the operation of ICAF on the Chrorella vulgaris algae showed that the algae population could be reduced to $99.98 \%$ at a current of $1 \mathrm{~A}$, a duration of $10 \mathrm{~min}$ and a concentration of $\mathrm{Cu}$ $(17.9 \pm 0.07 \mathrm{mg} / \mathrm{L})$. Meanwhile, the smallest decreasing reached $97.57 \%$ at electric current of $0.3 \mathrm{~A}$, the duration of $5 \mathrm{~min}$ and the concentration of $\mathrm{Cu}(15.52 \pm 0.25 \mathrm{mg} / \mathrm{L})$. This showed that the $\mathrm{Cu}$ ions that formed during the operation of the ICAF system can reduce the population of Chlorella vulgaris.

Isochrysis galbana was a species of Haptophyta with a species of the Isochrysis genus.
This microalgae species was an extraordinary food for shellfish larvae (Anonymous, 2016). On the other hand, Isochrysis galbana can cause biofouling. The other species of microalgae that can cause biofouling include Platymonas subcordiformis and Navicula, Barnacle nauplii (Dongdong et al., 2018). Botryococcus sp was a green pyramid-shaped planktonic microalgae that was potentially very important in the field of biotechnology. The colonies that were united by a lipid biofilm matrix can be found in lakes and oligotrophic estuaries of tropical or tropical climates, and it can bloom when the dissolved inorganic phosphorus levels increase. This species was famous for its ability to produce high amounts of hydrocarbons, especially oil in the form of Triterpenes, which were usually around $30-40 \%$ of their dry weight (Metzger and Largeau, 2005). Botryococcus sp has a relatively thick cell wall that was accumulated from the previous cellular divisions and making the extraction of cytoplasmic components rather difficult when compared to other green algae species. The majority of the useful hydrocarbon oil was outside the cell of Botryococcus sp (Wolf et al., 1985). Botryococcus sp has the ability to form biofilms (Zhang et al., 2018). The purpose of the research was to determine of reduction of the microalgae i.e. Isochrysis galba$n a$ and Botryococcus sp during the operation of a simple ICAF system.

\section{MATERIALS AND METHODS}

\section{Preparation of cathode and anode}

Steel material was applied in the field of marine buildings or ships. This material was be used as cathode with size of $15 \times 15 \times 1 \mathrm{~cm}$. Copper $(\mathrm{Cu})$ was applied as anode with similar cathode dimension.

\section{Propagation of microalgae}

The microalgae species of Isochrysis galbana and Botryococcus $s p$ were taken from $\mathrm{Ba}$ lai Perikanan Budidaya Air Payau (BPBAP) in Probolinggo. The propagation of Isochrysis galbana and Botryococcus sp was carried out using sterile artificial saline water. The salinity of sterile artificial saline water was $35 \%$, thus it was comparable with the salinity of the original seawater. The growth of Isochrysis galbana and 
Botryococcus sp was conducted at laboratory of Environmental Remediation in ITS campus. The intensity of light was 6000 to 8000 Lux during the propagation process and the duration was around 20 days. The ratio of sterile artificial saline water, Walne media and vitamin for Botryococcus $s p$ growing were $700 \mathrm{~mL}: 1 \mathrm{~mL}: 1 \mathrm{~mL}$ ). Afterwards, the $30 \%(\mathrm{v} / \mathrm{v})$ of Botryococcus sp stock were placed in that media. Meanwhile, the growth media for Isochrysis galbana were $700 \mathrm{~mL}$ of sterile artificial saline water, $1 \mathrm{~mL}$ of diatom fertilizer, $1 \mathrm{~mL}$ of vitamin, $1 \mathrm{~mL}$ of silicate, and $300 \mathrm{~mL}$ of Isochrysis galbana stock. All propagation reactors were stirred using a small mixer to homogenize the culture of microalgae during the growth process. Figure 1 described the propagation of microalgae.

\section{Operation of simple ICAF system}

The design of the simple ICAF system was carried out based the earlier research (Pratikno et al. 2019a,b; Pratikno and Titah, 2017, Pratikno and Titah, 2016). The operation of the simple ICAF system was conducted using a plastic reactor with the dimensions of $18 \times 10 \times 13 \mathrm{~cm}$. The distance of cathode and anode was $10 \mathrm{~cm}$. The volume of sterile artificial saline water was 1500
$\mathrm{mL}$ and the culture addition of Isochrysis galbanaamounted to $5 \%$. The similar stage was applied for reduction of Botryococcus sp. Microalgae of Botryococcus $s p$ culture was added in $1500 \mathrm{~mL}$ of sterile artificial saline water with $35 \%$ of salinity. Figure 2(a) described the operation of the simple ICAF system in the Isochrysis galbana culture which was carried out with variations in electrical wear and test time. Figure 2 (b) showed the operation of the simple ICAF system on the Botryococcus sp reduction.

The operation of ICAF system was carried out on the time variation $(5,7$ and $10 \mathrm{~min})$ and electrical current (0.1, 0.3, and 0.5 Ampere) based on the earlier study for bacteria. The determination of the number of cells of Isochrysis galbana and Botryococcus $s p$ was conducted using a Neubauer improved Hemocytomete method based on Perez (2006). The concentration of the $\mathrm{Cu}$ ions was analysed using Atomic Absorption Spectrophotometer (AAS).

\section{Determination of parameters}

A Neubauer improved Hemocytometer was calculated based on magnification microscope of $100 x$. The equation was used to measure the number of cells in a predetermined room.
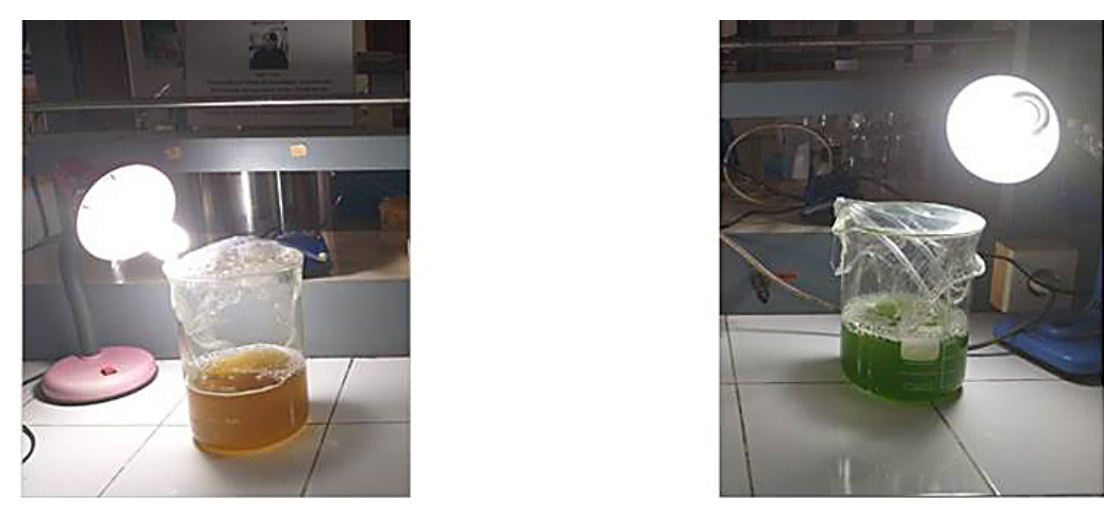

Figure 1. (a) Propagation of Isochrysis galbana and (b) Botryococcus sp culture
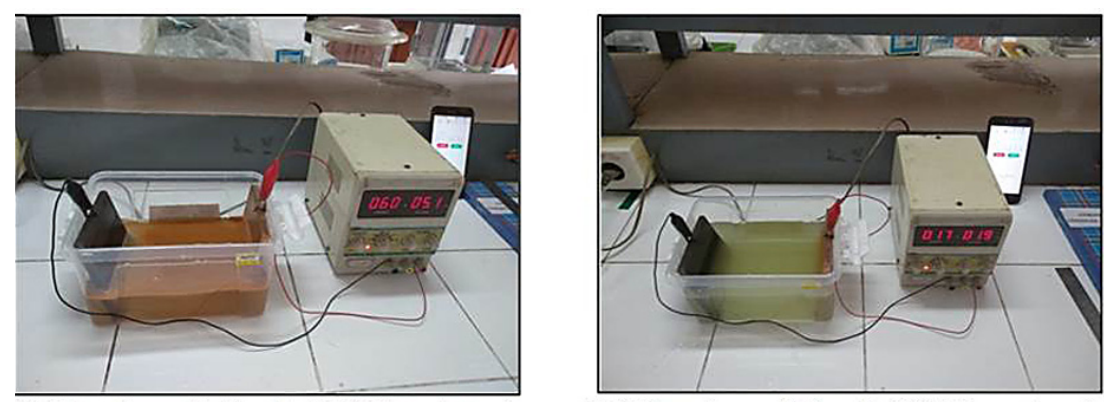

Figure 2. Operation of the simple ICAF system on Isochrysis galbana and Botryococcus sp reduction 


$$
\text { Average cells }=\frac{\text { cell visible }}{5 \text { squares }}
$$

Dillution Factor $=\frac{\text { Final volume after added diluent }}{\text { Diluted inoculum volume }}$

$$
\begin{aligned}
& \text { Cell density }(\text { cell } / \mathrm{mL})= \\
& \text { Average cells } x \text { Dillution Factor } \times 10^{4}
\end{aligned}
$$

The method to determine the $\mathrm{Cu}$ concentration was similar with the previous study (Pratikno et al. 2019a,b; Pratikno and Titah, 2017, Pratikno and Titah, 2016). The saline water samples were taken from the simple ICAF system reactor. Then, all samples were filtered using paper filter and analyzed using Atomic Absorption Spectrophotometer (AAS) model Z-2000 Series Hitachi (Japan) at Laboratory of Energy, LPPM ITS.

\section{RESULTS AND DISCUSSION}

\section{Population reduction of Isochrysis galbana}

Figure 3 showed the growth rate of Isochrysis galbana on sterile artificial seawater media with salinity of $35 \%$. This media artificial seawater media with salinity of $35 \%$ was added with media for diatoms, silicate and vitamins. According to Alkhamis and Qin (2013), Isochrysis galbana can live in a wide range of salinity, i.e. $10 \%$ to $60 \%$, but the optimal growth was reached at $35 \%$ of salinity. Other studies reported that Isochrysis galbana can live at the salinity of 5\% to $60 \%$ (Kaplan et al., 1986).

Liang and Utting (1980) reported that the optimal salinity in artificial seawater for the growth of Isochrysis galbana was in the range

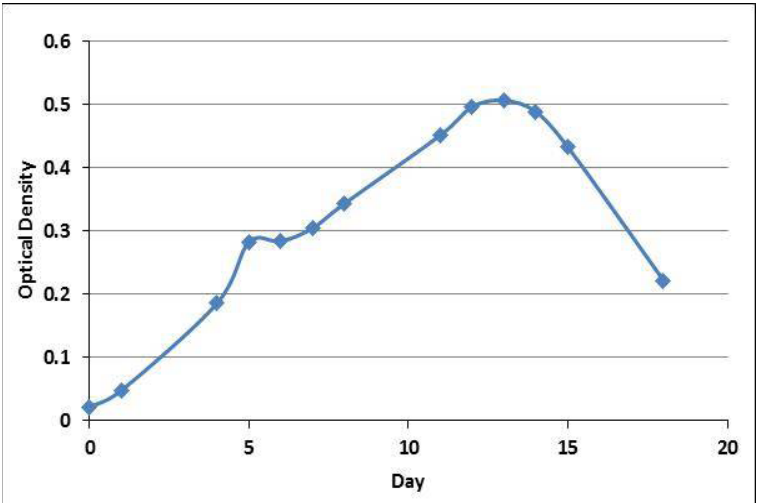

Figure 3. Growth rate curve of Isochrysis galbana of 15-25\%. Another study by Fabregas et al., (1984) reported that there was a close relationship between salinity and nutrients for the growth of Isochrysis galbana and the optimum growth of Isochrysis galbana occurred at the salinity of $15-35 \%$. The growth of Isochrysis galbana could be slow due to the increase in the salinity concentrations, occurring at 31-36\% (Liang and Utting, 1980). Aeration was carried out during the microalgae culturing process. The effects did not known between oxygen concentration, and the specific growth rate of microalgae with the addition of dissolved oxygen.

On the basis of the growth rate curve of Isochrysis galbana, the middle of log phase was reached at the age of 8 days. The age of Isochrysis galbana used in simple ICAF system was 8 days, according to the Isochrysis galbana growth rate curve.

Figure 4 showed the temperature during the simple ICAF system process on Isochrysis galbana. The temperature during testing was around $27^{\circ} \mathrm{C}$. According to Kaplan et al. (1986), Isochrysis galbana can grow well at temperatures above $19^{\circ} \mathrm{C}$. Another factor besides micronutrients and vitamins that affects the algae growth is $\mathrm{pH}$. Figure 5 shows the $\mathrm{pH}$ during the simple ICAF system process in Isochrysis galbana. The $\mathrm{pH}$ value during the test amounted to 8 . The Isochrysis galbana's response to $\mathrm{pH}$ variations was investigated (Grima et al., 1992). Grima et al., (1992) reported that the growth of Isochrysis galbana would be stunted if the $\mathrm{pH}$ was below 8 . The growth of Isochrysis galbana also started to be stunted if the $\mathrm{pH}$ was below 9 .

Figure 6 showed the decreasing in the number of Isochrysis galbana cells during the operation of a simple ICAF system. The higher the value of the electric current and the longer the

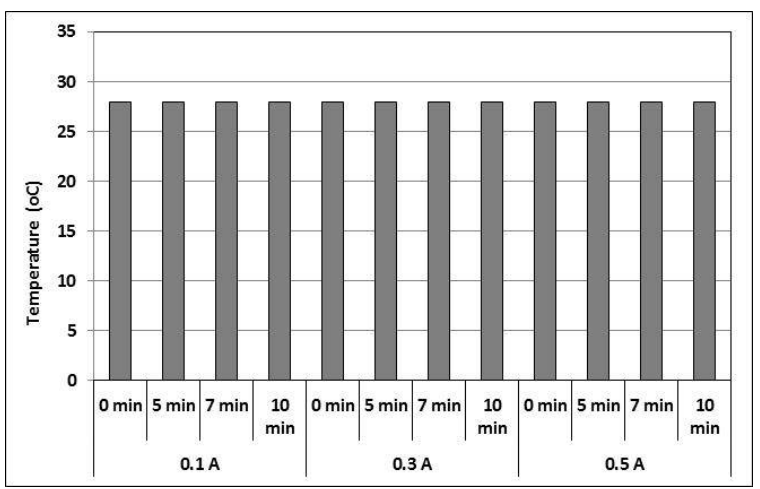

Figure 4. Temperature during the operation of the simple ICAF system 


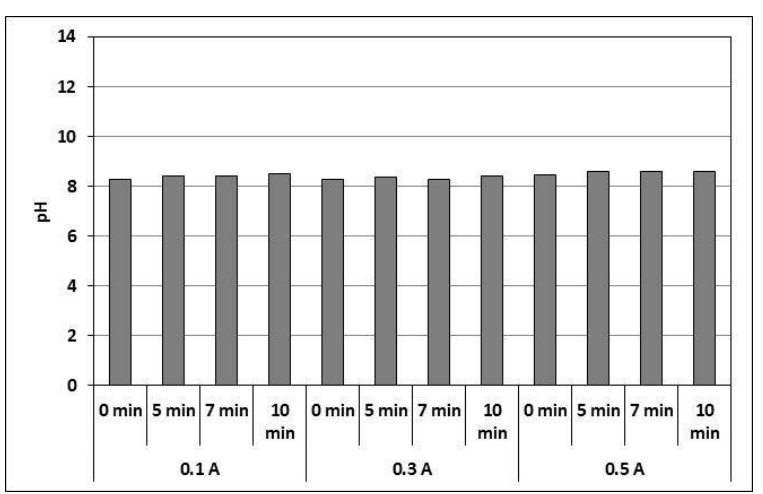

Figure 5. $\mathrm{pH}$ during the operation of the simple ICAF system

time, the greater the decreasing of Isochrysis galbana number cells. The percentage decrease in the number of Isochrysis galbana cells reached $77.5 \%$ (Figure 7 ).

According to Foulkes (2000), the ions of $\mathrm{Zn}$, $\mathrm{Cu}, \mathrm{Ni}, \mathrm{Co}, \mathrm{Mo}$, and $\mathrm{Cr}$ are essential trace elements for life. However, high concentrations of $\mathrm{Cu}$ will be toxic to organisms such as Isochrysis galbana. According to Liu et al., (2011), the effective concentration (EC50) value of $\mathrm{Cu}$ in Isochrysis galbana was $31.4 \mu \mathrm{mol} / \mathrm{L}$ equivalent to $7.9 \mathrm{mg} / \mathrm{L}$. According to Miazek et al. (2015), Isochrysis galbana has a $50 \%$ of growth inhibition on the $\mathrm{Cu}$ concentration of $0.01-0.018 \mathrm{mg} / \mathrm{L}$ with a time of $72 \mathrm{~h}$. The toxic effects of some heavy metals in Isochrysis galbana were as follows: $\mathrm{Cu}>\mathrm{Pb}>\mathrm{Cd}$ (Liu et al., 2011), so that Isochrysis galbana can be used as an indicator for toxicological bioassays.

Figure 8 showed the concentration of the $\mathrm{Cu}$ ions during operation of a simple ICAF system on Isochrysis galbana. The highest $\mathrm{Cu}$ ion concentration reached $2.5 \pm 0.08 \mathrm{mg} / \mathrm{L}$ at the highest electric current $(0.5 \mathrm{~A})$ and a operation time of $10 \mathrm{~min}$.

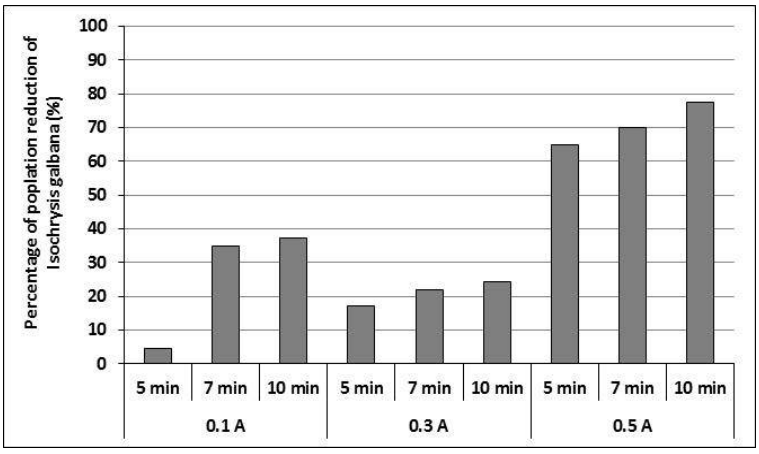

Figure 7. Reduction of Isochrysis galbana cells during the operation of the simple ICAF system

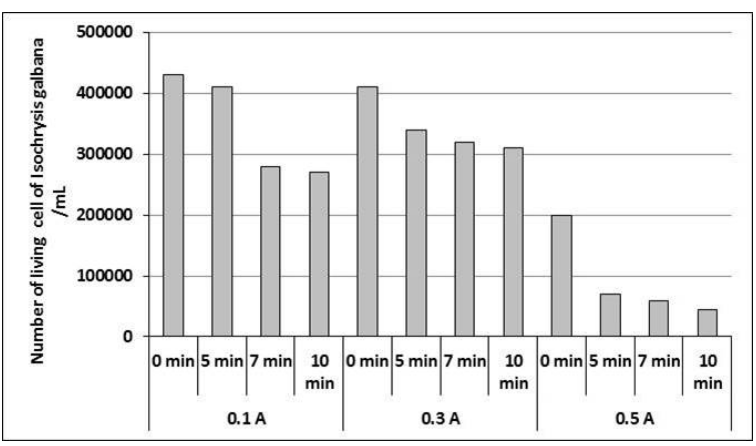

Figure 6. Number of cells of Isochrysis galbana during the operation of the simple ICAF system

\section{Population reduction of Botryococcus sp}

Figure 9 showed the growth rate curve of Botryococcus $\mathrm{sp}$ in artificial seawater at the salinity of 35\%. The growth of Botryococcus sp reached a half of the log phase at 8 or 9 days. Gani et al., (2017) reported that the middle of exponential phase of Botryococcus sp was 12 days. On the basis of these data, Botryococcus sp with a 9 day age was chosen for use in the operation of a simple ICAF system with a variety of electric currents and operating times.

Figure 10 showed the temperature during the simple ICAF system process in Botryococcus sp. The temperature during the testing was $27-28^{\circ} \mathrm{C}$. Lupi et al. (1991) reported that Botryococcus braunii cannot grow at temperature above $32^{\circ} \mathrm{C}$, and there were no previous studies which investigated the effect of temperatures below $18^{\circ} \mathrm{C}$ for the growth of Botryococcus braunii. According to Lee et al., (2015), the growth of Botryococcus braunii is optimum at a temperature of $25^{\circ} \mathrm{C}$. Figure 11 described the $\mathrm{pH}$ value during the simple ICAF system process in Botryococcus sp. The $\mathrm{pH}$ value during the test was 8 , or it was a normal $\mathrm{pH}$.

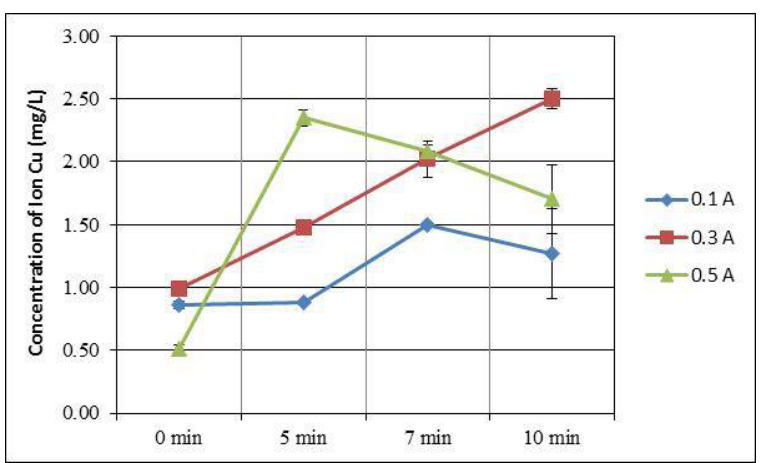

Figure 8. Concentration of $\mathrm{Cu}$ during the operation of the simple ICAF system 


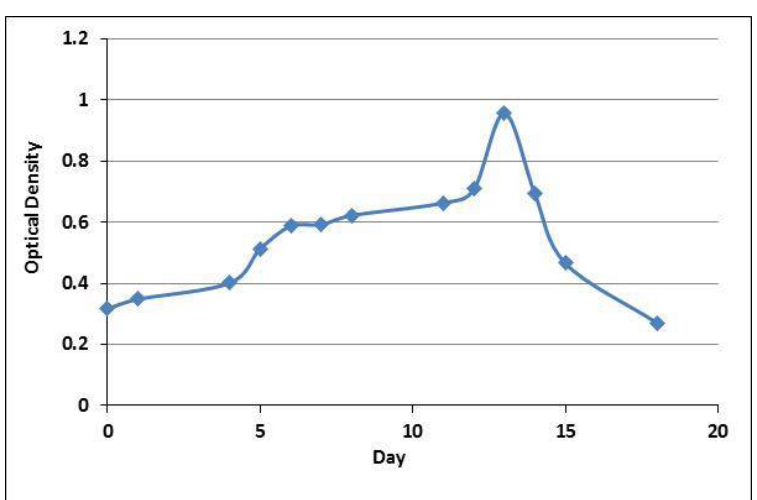

Figure 9. Growth of Botryococcus sp Curve

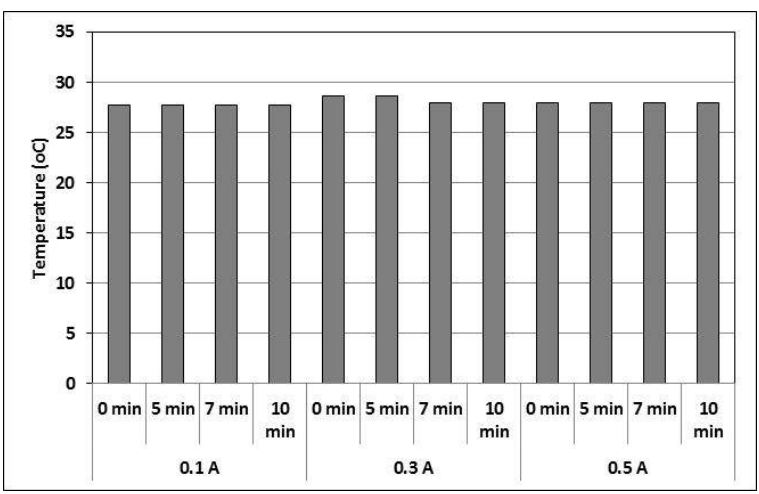

Figure 10. Temperature on Botryococcus sp during the operation of the simple ICAF system

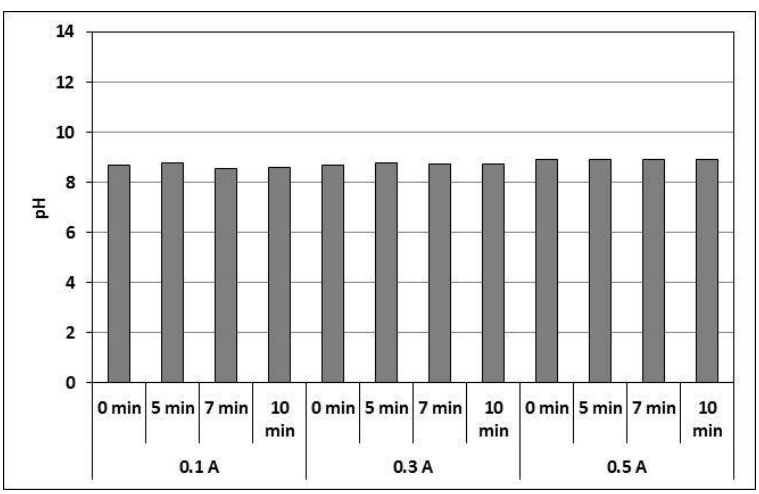

Figure 11. $\mathrm{pH}$ on Botryococcus sp during the operation of the simple ICAF system

Botryococcus microorganisms showed a variety of pH adaptability (Dayananda et al., 2017).

The population of Botryococcus sp in the operation of a simple ICAF system was shown in Figure 12. On the basis of this graph, the greater the value of the electric current and the longer the operation time, the lower the Botryococcus sp population. Figure 13 showed the percentage reduction in Botryococcus sp during the operation of the simple ICAF system. The highest

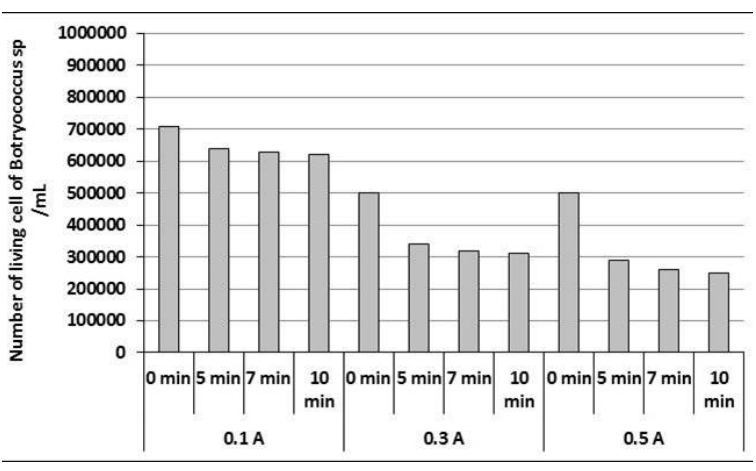

Figure 12. Number of Botryococcus sp cells during the operation of the simple ICAF system

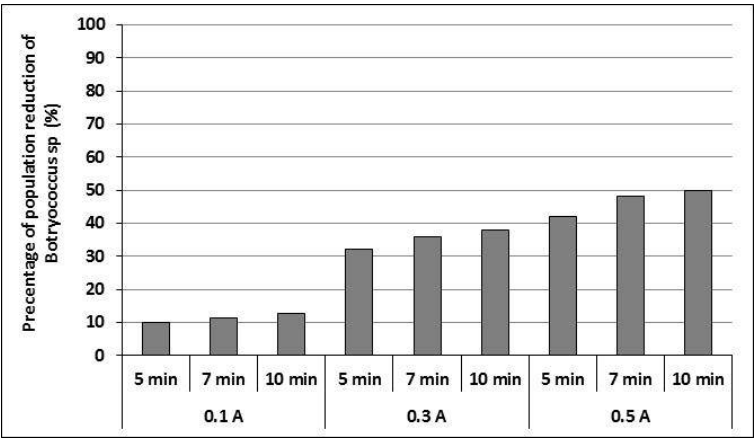

Figure 13. Reduction in the cell number of Botryococcus sp during the operation of the simple ICAF system

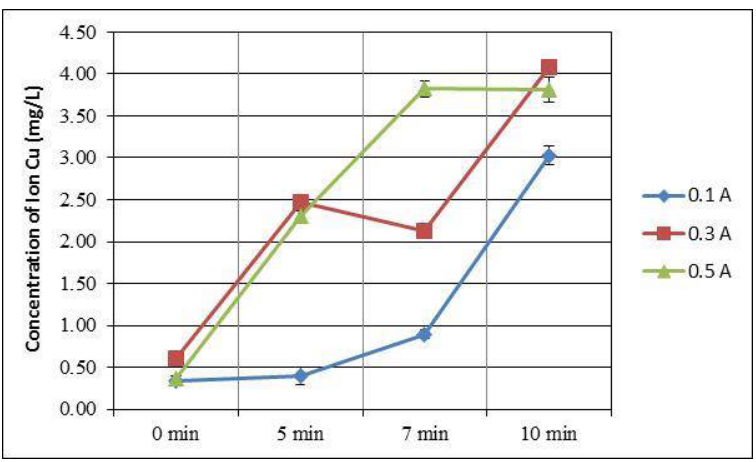

Figure 14. Concentration of $\mathrm{Cu}$ during the operation of thr simple ICAF system on Botryococcus sp

percentage reduction in Botryococcus sp population reached $50 \%$ in an electric current of $0.5 \mathrm{~A}$ and $10 \mathrm{~min}$ of operating time.

However, high concentrations of $\mathrm{Cu}$ can be toxic to Botryococcus sp. Some heavy metals i.e. $\mathrm{Cu}, \mathrm{Ni}$ and $\mathrm{Fe}$ were metals that were usually observed to have toxic properties on algae, if the concentration of those heavy metals were above the trace element concentration limit. $\mathrm{Cu}$ was one of the most toxic metals (Juneja et al. 2013). 
Toxic metals can inhibit carbon fixation and delay the absorption of nutrients in algae (Rai and Mallick, 1993). Figure 14 showed the concentration of the $\mathrm{Cu}$ ions during the operation of the simple ICAF system on Botryococcus sp. The highest $\mathrm{Cu}$ ion concentration reached $4.08 \pm 0.01 \mathrm{mg} / \mathrm{L}$.

\section{CONCLUSIONS}

The highest decrease in the cell number of Isochrysis galbana and Botryococcus sp reached $77.5 \%$ and $50 \%$ at the highest electric current $(0.5 \mathrm{~A})$ and a operation time of $10 \mathrm{~min}$, respectively. The highest concentration of $\mathrm{Cu}$ reached $4.08 \pm \mathrm{mg} / \mathrm{L}$. In conclusion, the $\mathrm{Cu}$ ion that was produced during the operation of the simple ICAF system can reduce the cell number of Isochrysis galbana and Botryococcus sp.

\section{Acknowledgements}

The author would like to thank KemenristekDIKTI (Ministry of Research, Technology and Higher Education, Republic of Indonesia) Perguruan through scheme of Penelitian Dasar Unggulan Perguruan Tinggi - second year research, PTUPT 2019 for funding this research with No of contract, 5/E1/KP.PTNBH/2019.

\section{REFERENCES}

1. Allal, A. A., Mansouri, K., Youssfi, M., and Qbadou, M. 2017. Toward a reliable sea water central cooling system for a safe operation of autonomous ship. Conference: International Conference on Recent Innovations in Engineering and Technology (ICRIET) at Berlin, Germany.

2. Cao, S., Wang, J., Chen, H., and Chen, D. 2011. Progress of marine biofouling and antifouling technologies. Chinese Science Bulletin, 56, 598-612. doi: 10.1007/s11434-010-4158-4

3. Azam, F., and Malfatti, F. 2007. Microbial structuring of marine ecosystems. Nature Review Microbiology, 5, 782-791. doi: 10.1038/ nrmicro1747

4. Cooksey, K. E., and Wigglesworth-Cooksey, B. 1995. Adhesion of bacteria and diatoms to surfaces in the sea: a review. Aquatic Microbiology and Ecology, 09, 87-96. doi: 10.3354/ame009087

5. Pratikno, P., and Titah, H.S. 2016. Microbial Influenced Corrosion on Aluminium by Pseudomonas fluorescens in different saline water. International Journal of ChemTech Research, 9(12): 600-609.
6. Botsford, J.L. 1998. A simple assay for toxic chemical using a bacterial indicator. World J. Microbiolal Biotechnology, 14: 369-376.

7. Pratikno, P., Titah, H.S., and Handayanu. 2019a. Reduction of Vibrio Alginolyticus Population in System Impressed Current Anti Fouling (ICAF) For Biofouling Prevention. International Journal of Civil Engineering and Technology, 10(1): 1507-1514

8. Pratikno, P., and Titah, H.S. 2017. Bio-corrosion on Aluminium 6063 by Escherichia coli in Marine Environment. IPTEK, The Journal for Technology and Science, 28(2): 55-58.

9. Pratikno, P., Titah, H.S., and Handayanu. 2019b. Impressed Current Anti Fouling (ICAF) to Reduce Population of Chlorella Vulgaris Cause Bio Corrosion on AH36 Steel in Marine Environment. International Conference on Energy, Environment, Epidemiology and Information System (ICENIS), E3S Web of Conferences 125 DOI: https://doi. org/10.1051/e3sconf/201912506001

10. Anonymous. 2016. Training Manual on Live Feed for Marine Finfish and Shellfish Culture. Visakhapatnam Regional Centre Icar-Central Marine Fisheries Research Institute Ocean View Layout, Pandurangapuram Visakhapatnam - 530003.

11. Dongdong, L., Miao, D., Jianxin, Y., and Qiang, L. 2018. Performance of Marine Bioactivities of NAcyloxyethyl-1,2-Benzisothiazol-3(2H)-one Antifouling Paint. IOP Conference Series: Materials Science and Engineering 382.

12. Metzger, P., Largeau, C. 2005. Botryococcus braunii : sumber yang kaya akan hidrokarbon dan lipid eter terkait".Mikrobiologi Terapan dan Bioteknologi. 66 (25): 486-96. doi : 10.1007 / s00253-004-1779-z

13. Wolf, Fred, R., Nonomura, Arthur M, Bassham, James, A. 1985. Pertumbuhan dan Produksi Hidrokarbon bercabang dalam Strain Botryococcus braunii (Chlorophyta). Jurnal Phycology. 21 (3): 388. doi : 10.1111 / j.0022-3646.1985.00388.x

14.Zhang, X., Gao, P., Hollimon, V., Brodus, D., Johnson, A., and Hu, H. 2018. Surface thiolation of silicon for antifouling application. Chemistry Central Journal 12:10 https://doi.org/10.1186/ s13065-018-0385-6

15. Perez. S. 2006. Cell counts using Improved Neubauer haemocytometer.

16. Alkhamis, Y., and Qin, J.G. 2013. Cultivation of Isochrysis galbana in Phototrophic, Heterotrophic, and Mixotrophic Conditions. Hindawi Publishing Corporation BioMed Research International 1-9. http://dx.doi.org/10.1155/2013/983465

17. Kaplan, D., Cohen, Z., and Abeliovich A. 1986. Optimal growth conditions for Isochrysis galbana. Biomass, 9(1), 37-48. 
18. Liang, I, and S.D. Utting. 1980. The influence of salinity on the production of two comercially importanta unicellular marine algae. Aquaculture, 21: 79-86.

19. Fabregas, J., Herrero, C., Abalde, J., and Cabezas, B. 1984. Growth of marine microlagae Tetraselmis suecica in batch cultures with different salinities and nutrient concentrations. Aquaculture, 42: 2017-2015.

20. Raso, S., van Genugten, B., Vermuë, M., and Wijffels, R. H. 2012. Effect of oxygen concentration on the growth of Nannochloropsis sp. at low light intensity. J Appl Phycol, 24:863-871

21. Grima, E. M, Srinchez Pez, J. A., Garcia Siinchez, J. L., Garcia Camachoa F., and Lpez Alonso, D. 1992. EPA from Isochrysis galbana. Growth Conditions and Productivity. Process Biochemistry, 27: 299-305.

22. Foulkes, E.C. 2008. Transport of Toxic Heavy Metals Across Cell Membranes. Proceedings of the Society for Experimental Biology and Medicine, 223(3). 234-240.

23. Liu, G., Chai, X., Shao, Y., Hu, L., Xie, Q., and Wu, Q. 2011. Toxicity of copper, lead, and cadmium on the motility of two marine microalgae Isochrysis galbana and Tetraselmis chui. Journal of Environmental Sciences, 23(2): 330-335.

24. Miazek, K., Iwanek, W., Remacle, C., Richel, A., and Goffin, D. 2015. Effect of Metals, Metalloids and Metallic Nanoparticles on Microalgae Growth and Industrial Product Biosynthesis: A Review.
Int. J. Mol. Sci. 16, 23929-23969; doi:10.3390/ ijms161023929

25. Gani, P., Sunar, N.M., Matias-Peralta, H., Mohamed, R.M.S.N., Latiff, A.A., and Parjo, U. K. 2017. Extraction of hydrocarbons from freshwater green microalgae (Botryococcus sp.) biomass after phycoremediation of domestic wastewater, International Journal of Phytoremediation, 19:7, 679-685, DOI: $10.1080 / 15226514.2017 .1284743$

26. Lupi, F.M., H.M.L. Fernandes, I. SaCorreia, and J.M. Novais. 1991. Temperature profiles of cellular growth and exopolysaccharide synthesis by Botryococcus braunii Kütz. UC 58. J. Appl. Phycol. 3, 35-42.

27. Lee, C-H. , Chae, H-S., Lee, S-H., and Kim H.S. 2015. Growth characteristics and lipid content of three Korean isolates of Botryococcus braunii (Trebouxiophyceae). Journal of Ecol. Environ. 38(1): 67-74.

28. Dayananda, C., Sarada, R., Kumar, V., and Ravishankar, G.A. 2017. Isolation and characterization of hydrocarbon producing green alga Botryococcus braunii from Indian freshwater bodies. Electronic Journal of Biotechnology. 10(1): 78-91.

29. Juneja, A., Ceballos, R. M., and Murthy, G.S. 2013. Effects of Environmental Factors and Nutrient Availability on the Biochemical Composition of Algae for Biofuels Production: A Review. Energies 6, 4607-4638. doi:10.3390/en6094607

30. Rai, L., and Mallick, N. 1993. Heavy metal toxicity to algae under synthetic microcosm. Ecotoxicology. 2, 231-242. 
